University of Arkansas, Fayetteville

ScholarWorks@UARK

Education Reform Faculty and Graduate

Students Publications

4-5-2017

\title{
Examining the Impacts of Middle School Disciplinary Policies on 9th Grade Retention
}

\author{
Elise Swanson \\ University of Arkansas, Fayetteville, eswanson@uark.edu \\ Heidi Holmes Erickson \\ University of Arkansas, Fayetteville \\ Gary W. Ritter \\ University of Arkansas, Fayetteville
}

Follow this and additional works at: https://scholarworks.uark.edu/edrepub

Part of the Educational Assessment, Evaluation, and Research Commons, Educational Leadership Commons, and the Other Educational Administration and Supervision Commons

\section{Citation}

Swanson, E., Holmes Erickson, H., \& Ritter, G. W. (2017). Examining the Impacts of Middle School Disciplinary Policies on 9th Grade Retention. Education Reform Faculty and Graduate Students Publications. Retrieved from https://scholarworks.uark.edu/edrepub/9

This Article is brought to you for free and open access by the Education Reform at ScholarWorks@UARK. It has been accepted for inclusion in Education Reform Faculty and Graduate Students Publications by an authorized administrator of ScholarWorks@UARK. For more information, please contact scholar@uark.edu. 


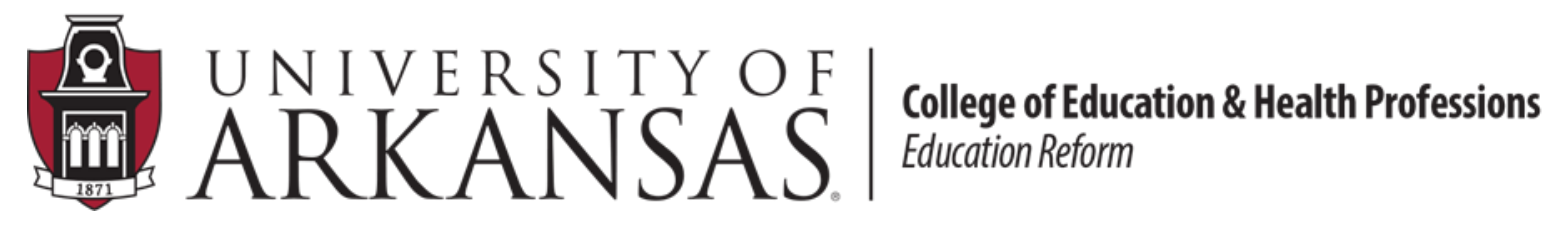

\title{
WORKING PAPER SERIES
}

\section{Examining the Impacts of Middle School Disciplinary Policies on $9^{\text {th }}$ Grade Retention}

\author{
Elise Swanson \\ University of Arkansas \\ Heidi Holmes Erickson \\ University of Arkansas \\ Gary W. Ritter, Ph.D. \\ University of Arkansas
}

Last Revised April 5, 2017

EDRE Working Paper 2017-11

The University of Arkansas, Department of Education Reform (EDRE) working paper series is intended to widely disseminate and make easily accessible the results of EDRE faculty and students' latest findings. The Working Papers in this series have not undergone peer review or been edited by the University of Arkansas. The working papers are widely available, to encourage discussion and input from the research community before publication in a formal, peer reviewed journal. Unless otherwise indicated, working papers can be cited without permission of the author so long as the source is clearly referred to as an EDRE working paper. 


\begin{abstract}
In this paper we estimate the impact of exclusionary discipline given in $8^{\text {th }}$ grade on the probability of $9^{\text {th }}$ grade retention. We use a rich seven year, student level, panel dataset from Arkansas. We use a novel approach by limiting our sample to students who switch schools between $8^{\text {th }}$ and $9^{\text {th }}$ grade. This movement gives each student a fresh start, and removes the potential confound of a student's reputation as a "problem student" that could influence teachers to be harsher on students who already have a disciplinary record. We find that students who receive exclusionary discipline in $8^{\text {th }}$ grade are more likely to be retained in $9^{\text {th }}$ grade compared to students who received no exclusionary discipline. We find nominal evidence that the impact of exclusionary discipline is attenuated for students of color and students receiving FRL; however, the differences are not significant.
\end{abstract}

Keywords: school discipline, exclusionary discipline, grade retention impacts 


\section{Introduction and Research Questions}

Exclusionary discipline has become a highly debated issue within K12 education across the United States for numerous reasons. Both in-school and out-of-school suspensions have been shown to be associated with lower levels of student academic achievement and increased rates of dropping out before completing high school (Noltemeyer, Ward, and Mcloughlin, 2015). However, the causal connection between school discipline and student outcomes is uncleardoes exclusionary discipline cause students to miss class time, feel alienated, perform worse, become demoralized, and drop out? Or do low-achieving students act out, prompting a disciplinary response, followed by continued low academic performance?

These mechanisms are difficult to disentangle, particularly when attempting to look at medium and long-term outcomes for students who spend multiple years on the same school campus. It is certainly possible that a student's disciplinary record may act as a signal to other teachers that a student deserves extra scrutiny and causes them to discipline the student for behaviors that would be tolerated in other children. In this paper, we examine students at critical juncture in their academic career in an attempt to estimate the impact of exclusionary discipline on future school performance while also dealing with possible issues of reverse causality. Specifically, we consider junior high school students in grade eight with similar behavioral records and academic records; despite the similarities, some of these students received exclusionary discipline (out-of-school suspension, expulsion, alternative learning environment) while some did not. Given this variation, we will investigate whether the exclusionary discipline affected academic performance in grade nine. Finally, rather than measuring academic performance based on standardized test scores, we will use on-time promotion to grade ten as our outcome measure. 
We use a rich seven year student-level panel data set from the state of Arkansas from 2008-09 to 2014-15. We hypothesize that students who receive exclusionary discipline in $8^{\text {th }}$ grade are more likely to be retained in $9^{\text {th }}$ grade, controlling for other student characteristics and predictors of grade retention. We focus on the relationship between exclusionary discipline given in $8^{\text {th }}$ grade and retention in $9^{\text {th }}$ grade because many students switch schools between these grades. Limiting our sample to students who switch schools removes any potential bias created by a student's past disciplinary record on the decision to retain a student in the following year. This removes bias in our estimates of the relationship between exclusionary discipline and student outcomes.

The paper is organized as follows. First, we summarize the relevant literature. Second, we give a brief overview of discipline and retention policies in Arkansas. Third, we describe our data and methods. Next, we present the results and discuss policy implications.

\section{Literature Review}

In this section, we briefly summarize the literature on the impacts of exclusionary discipline on student outcomes, focusing specifically on the relationship between exclusionary discipline and student academic achievement, as we believe this may shed light on our outcome of interest, in-grade retention. Furthermore, because grade retention is a relatively unused outcome measure, we will describe the literature examining the potential impacts of grade retention.

\section{Exclusionary Discipline}

Exclusionary discipline has become a highly debated issue in education. Exclusionary discipline has increased as zero-tolerance policies have spread through many schools in the past twenty years. Zero-tolerance policies were designed to dissuade students from acting out in fear of the consequences. Many students receive exclusionary discipline under zero tolerance. These 
policies have resulted in an increased number of students out of school for disciplinary actions and increased students contact with law enforcement (Skiba, 2014). It is important to note that exclusionary discipline is not exclusively used for violent or other major student infractions. It is commonly used for relatively minor non-violent infractions such as insubordination (RaffaeleMendez, Knoff, and Ferror, 2002). In Arkansas, the majority of infractions are minor non-violent infractions.

Exclusionary discipline can affect student academic achievement. In a meta-analysis summarizing 34 different studies, Noltemeyer and Ward (2015) found an inverse relationship between suspension and academic achievement and a positive relationship between suspensions and a student dropping out of school. They found that in school suspension (ISS) was associated with a 0.10 standard deviation decrease in achievement, and out of school suspension was associated with a 0.24 standard deviation decrease in achievement. Out of school suspension (OSS) was also associated with a 0.25 standard deviation increase in the likelihood of a student dropping out. Similarly, using data from North Carolina, Beck and Muschkin (2012) found that the number of infractions a student received was associated with a decrease in achievement. They found that each additional infraction was associated with a 0.02 standard deviation decrease in achievement for white students and a 0.06 standard deviation decrease in achievement for black students. While these results are suggestive of a negative relationship between exclusionary discipline and academic achievement, the majority of studies are simply correlational, and do not prove the direction the relationship: whether exclusionary discipline leads to worse academic outcomes, or whether low academic achievement leads students to act out in school. 
There is also evidence of racial and gender disparities between students who received and did not receive exclusionary discipline. Using national data, Losen et al. (2015) found that OSS rates have been increasing broadly, but they have been dramatically increasing for black student compared to their white and Hispanic counterparts. They find that black students are three times more likely to be suspended. Losen and Skiba (2010) found similar results using data from eighteen large urban districts. They found that black male students were suspend at twice the rate of their white male counterparts. Raffaele-Mendez (2003) and Raffaele-Mendez, Knoff, and Ferror (2002) used data from Florida school districts and found that male and female black students were disproportionally suspended, and black students who also qualified for FRL were suspended more often than black students who did not qualify for FRL.

The existing literature suggests that receiving exclusionary discipline is related to diminished student academic achievement, and that disadvantaged students (particularly black students and students who receive FRL) are disproportionately likely to face exclusionary discipline. We hypothesize that exclusionary discipline also hurts students' non-cognitive skills and engagement with school, which puts them at risk for in-grade retention. Further, we anticipate that disadvantaged students will be most hurt by these policies, as they are less likely than more advantaged students to have a support system that could help them rebound from the experience of being sent out of school, or that could advocate for on-time promotion with a teacher or administrator.

\section{Grade Retention}

We briefly summarize the literature on grade retention because of its close relation with academic achievement. We use grade retention as our outcome of interest as an alternative 
measure of academic achievement. Grade retention is a highly debated policy aimed at helping students who are performing below grade level. The goal of retention is to keep students in the same grade for an additional year so they can overcome their achievement deficit. It is argued that in order to provide a meaningful education, students should be retained to help them succeed in later grades and post school. A body of literature, primarily looking at retention in early grades, shows that grade retention does not harm students long term and can help increase achievement (Greene and Winters, 2012; Schwerdt and West, 2012; Jacob and Lefgren, 2004).

There is also a body of research showing that grade retention can harm student achievement and long term outcomes (Jimerson, 2001; Jimerson, 1999; Holmes, 1989). It is argued that retained students face additional social pressures and a stigma from peers and teachers from being held back. As a results they disengage from school and continue to struggle academically. Jimerson 2001 summarizes three meta-analyses examining the effects of grade retention on academic and socioemotional outcomes. All three meta-analyses find negative relationships of grade retention and academic and socioemotional outcomes. The analyses, however, do not distinguish between grade retention in high and lower grades. In another systematic review Jimerson, Anderson, and Whipple (2002) analyze 17 studies that look at the possible long term effects from grade retention. They find that retention in early and later graders is one of the strongest predictors of a student dropping out.

There is a small body of literature looking at the relationship between school discipline and grade retention. There are competing theories of how discipline and retention affect each other. First, it is possible that students who are retained act out due to social pressures and an associated stigma of being held back in a grade. Students could feel alienated because they are older than other students in their grade and act out as a result. Another theory is that students 
who receive exclusionary discipline are more likely to be retained in grade because they miss class time, which harms their achievement. Students could also feel that they have been punished unfairly and disengage in school, which in turn harms their achievement and leads to a higher probability of being retained.

It can be difficult to disentangle the relationship between discipline and academic achievement generally (and grade retention in particular) because there is a possible reciprocal relationship. Using regression discontinuity, Özek (2015) found that grade retention in early grades has a significant positive effect on disciplinary actions. He concluded that students who were just below the cut off for grade promotion were more likely to be suspended in the two years following retention. These results were more prevalent among black, male, and economically disadvantaged students. These effects faded out within three years following retention. Muschkin, Glennie, and Beck (2014) uncovered a similar relationship using data of $7^{\text {th }}$ graders in North Carolina. They found that retained students had negative peer effects. A one percent increase in the number of retained students in a school increased the odds of an individual student being written up by three percent.

This paper seeks to expand the literature on the relationship between exclusionary discipline and academic achievement by focusing on student retention. We hypothesize that students who receive exclusionary discipline will have a higher probability of being retained. We are particularly interested in the impact of exclusionary discipline given in junior high school (specifically $8^{\text {th }}$ grade) on student outcomes in $9^{\text {th }}$ grade, which marks the start of a student's high school career. Grade retention is relative holistic academic measure, in that it represents overall academic progress (rather than simply test scores), and as such is an important outcome for students. Consequently, it is very important that policymakers and school leaders understand the 
extent of the independent relationship (if indeed there is one) between exclusionary discipline and grade retention.

We take a novel approach by looking at the probability of retention in $9^{\text {th }}$ grade as a function of exclusionary discipline in $8^{\text {th }}$ grade for students who switch schools between $8^{\text {th }}$ and $9^{\text {th }}$ grade. Limiting our sample to students who switch schools helps eliminate bias created by a stigma attached to students with disciplinary records. We are also test if there is a dosage effect: do students who receive more days of exclusionary discipline have a higher probability of being retained? With this general picture of the impacts of exclusionary discipline and grade retention, we move now to a discussion of how these policies are implemented in Arkansas.

\section{Discipline and Retention in Arkansas}

Arkansas has eighteen different infraction categories in which teachers can record student misbehavior, and eight different potential consequences. Table 1 contains each infraction type and the available consequences. The state provides general disciplinary reporting guidelines, but specific policies are determined by school districts and individual schools. For example, the state of Arkansas allows corporal punishment; however, not every district uses it. School administrators and teachers have discretion in what behaviors they report as infractions and what consequences they assign. In this paper, we focus on exclusionary discipline including out of school suspension (OSS), expulsion, and alternative learning environments (ALE). In our sample of Arkansas $8^{\text {th }}$ and $9^{\text {th }}$ graders who switch school between $8^{\text {th }}$ and $9^{\text {th }}$ grade, $13 \%$ of students 
received exclusionary discipline for an average of 7.33 days, with a mode of three days, and maximum of 131 days (Table 2).

Table 1: Arkansas Infraction Categories

\begin{tabular}{|c|c|c|c|}
\hline Infraction Category & Specific Infractions & $\begin{array}{l}\text { \% of 8th Grade } \\
\text { Infractions }\end{array}$ & $\begin{array}{l}\text { Potential } \\
\text { Consequences }\end{array}$ \\
\hline Drugs and Alcohol & Alcohol, drugs, tobacco & $2.28 \%$ & \multirow{5}{*}{$\begin{array}{l}\text { ALE, corporal } \\
\text { punishment, } \\
\text { expulsion, ISS, } \\
\text { OSS, no action, } \\
\text { other action, }\end{array}$} \\
\hline Weapon & Knife, gun, explosives & $0.29 \%$ & \\
\hline Violent & $\begin{array}{c}\text { Bullying, club, fighting, staff } \\
\text { assault, student assault }\end{array}$ & $10.52 \%$ & \\
\hline Major Non-Violent & Gangs, vandalism & $0.73 \%$ & \\
\hline Minor Non-Violent & $\begin{array}{l}\text { Truancy, disorderly conduct, } \\
\text { insubordination, other } \\
\text { infraction }\end{array}$ & $86.18 \%$ & \\
\hline
\end{tabular}

Table 2: Distribution of Number of Days of Exclusionary Discipline for Students who Switch School from $8^{\text {th }}-9^{\text {th }}$ grade

\begin{tabular}{lc}
$\begin{array}{l}\text { Days of Exclusionary } \\
\text { Discipline }\end{array}$ & Number of Students \\
\hline $1-5$ & 1,878 \\
$6-10$ & 764 \\
$11-15$ & 267 \\
$16-20$ & 106 \\
$21-25$ & 72 \\
$26+$ & 108 \\
\hline Total & 3,195 \\
\hline$* *$ Mean number of days was 7 with a mode of 3 days
\end{tabular}

Districts also have discretion in determining grade retention. Students who do not pass all end-of-year courses or who are missing credits can be considered for retention. Before a decision is made, a meeting between the school principal, teachers, and parents/guardians is convened to discuss the needs to the student and set an Individualized Academic Improvement Plan (IAIP). If there is any disagreement regarding whether the student should be retained, the final decision rests with the principal. In our sample of students who switch schools between $8^{\text {th }}$ and $9^{\text {th }}$ grade, $14 \%$ of students were retained in $9^{\text {th }}$ grade. 


\section{Data}

We use a seven year panel dataset which includes all student records in Arkansas from 2008-09 to 2014-15, including type of disciplinary infraction and corresponding consequence, demographic characteristics, and academic outcomes. We limit our analysis to a subsample of students who switch schools between $8^{\text {th }}$ and $9^{\text {th }}$ grade. Moving schools gives students a fresh start who have been labeled as a "problem student" due to previous infractions. Limiting our analysis to those who switch schools removes the potential bias of school administrators and teachers retaining students because of the student reputation based on their prior discipline history.

Even limiting our sample, we still have a large sample. There are $304,1098^{\text {th }}$ and $9^{\text {th }}$ grade students in all seven years of data, with $24,0358^{\text {th }}$ and $9^{\text {th }}$ graders attending schools that terminate in $8^{\text {th }}$ grade. To better illustrate the proportion of Arkansas students included in our subsample, in the 2014-2015 school year there were $34,7979^{\text {th }}$ grade students who also attended $8^{\text {th }}$ grade in Arkansas in 2013-2014. Of the $34,7979^{\text {th }}$ graders, there were 3,963 students in schools were $9^{\text {th }}$ grade was the lowest grade. Table 6 shows demographic information for various groups of student. The population of students who switch schools (column 5) is generally demographically representative of the all $8^{\text {th }}$ and $9^{\text {th }}$ graders in Arkansas (column 2). Among the subsample of students who switch schools, there are roughly equal proportions of students who were previously retained, and who qualify for FRL or LEP services. There is a slightly greater share of black and female students and a lower fraction of white students. The majority of schools that begin in 9th are located in the Central region, which includes Little Rock and other large districts, as opposed to other areas of the state that are more rural and tend to have a single school for grades 7-12 and that tend to serve disproportionately high fractions of white students. When comparing all students who were retained in $9^{\text {th }}$ grade (column 7) and those who were 
retained and switched schools (column 8), there are similar proportions of students who have been previously retained and students that qualify for FRL. However, there are more students of color retained in schools starting in $9^{\text {th }}$ grade. Students who receive exclusionary discipline (column 3) and those who are retained in $9^{\text {th }}$ grade (column 7 and 8 ) are disproportionately black, male and quality for FRL compared to all $8^{\text {th }}$ and $8^{\text {th }}$ graders (column 2). Students who received exclusionary discipline in $8^{\text {th }}$ grade and students who were retained in $9^{\text {th }}$ grade have also been retained at higher rates in previous grades than their counterparts. 
Table 3: Student Demographics from 2008-2009 to 2014-2015

\begin{tabular}{|c|c|c|c|c|c|c|c|c|c|}
\hline & $(1)$ & $(2)$ & (3) & (4) & $(5)$ & (6) & (7) & $(8)$ & $(9)$ \\
\hline & $\begin{array}{r}\text { All } \\
\text { Students }\end{array}$ & $\begin{array}{r}\text { 8th \& 9th } \\
\text { Grade } \\
\text { Students }\end{array}$ & $\begin{array}{r}\text { 8th \& 9th } \\
\text { Grade Student } \\
\text { w/Exclusionary } \\
\text { Discipline }\end{array}$ & $\begin{array}{r}\text { 8th Grade } \\
\text { Students } \\
\text { w/Exclusionary } \\
\text { Discipline }\end{array}$ & $\begin{array}{r}\text { Students } \\
\text { who Switch } \\
\text { Schools } \\
\text { from 8th- } \\
\text { 9th }\end{array}$ & $\begin{array}{r}\text { Students who } \\
\text { Switch School } \\
\text { w/ 8th } \\
\text { Exclusionary } \\
\text { Discipline }\end{array}$ & $\begin{array}{r}\text { 9th } \\
\text { Grade } \\
\text { Students } \\
\text { Retained }\end{array}$ & $\begin{array}{r}\text { 9th Grade } \\
\text { Students } \\
\text { Retained } \\
\text { who } \\
\text { Switched } \\
\text { Schools } \\
\end{array}$ & $\begin{array}{r}\text { Student who } \\
\text { Switch Schools } \\
\text { w/8th } \\
\text { Exclusionary } \\
\text { Discipline \& } \\
\text { Retained in 9th } \\
\end{array}$ \\
\hline$N$ & 806,762 & 304,109 & 39,139 & 22,877 & 24,035 & 3,195 & 8,685 & 3,286 & 722 \\
\hline White & $63.9 \%$ & $65.4 \%$ & $42.6 \%$ & $40.4 \%$ & $49.9 \%$ & $32.1 \%$ & $44.2 \%$ & $36.7 \%$ & $25.1 \%$ \\
\hline Total Minority & $35.2 \%$ & $34.4 \%$ & $57.4 \%$ & $59.6 \%$ & $50.1 \%$ & $67.9 \%$ & $55.9 \%$ & $63.3 \%$ & $75.1 \%$ \\
\hline Black & $21.0 \%$ & $21.5 \%$ & $47.3 \%$ & $50.3 \%$ & $38.7 \%$ & $60.9 \%$ & $43.1 \%$ & $48.7 \%$ & $68.1 \%$ \\
\hline Hispanic & $10.6 \%$ & $9.3 \%$ & $7.6 \%$ & $6.9 \%$ & $9.2 \%$ & $5.2 \%$ & $10.3 \%$ & $12.3 \%$ & $5.5 \%$ \\
\hline Two or More & $1.6 \%$ & $0.9 \%$ & $1.2 \%$ & $1.2 \%$ & $0.9 \%$ & $1.0 \%$ & $0.8 \%$ & $0.9 \%$ & $0.8 \%$ \\
\hline Other & $2.0 \%$ & $2.6 \%$ & $1.3 \%$ & $1.2 \%$ & $1.3 \%$ & $0.8 \%$ & $1.6 \%$ & $1.4 \%$ & $0.6 \%$ \\
\hline $\begin{array}{l}\text { Retention Prior to } \\
\text { 9th Grade }\end{array}$ & & $1.6 \%$ & $5.0 \%$ & $7.0 \%$ & $2.0 \%$ & $5.9 \%$ & $4.3 \%$ & $3.6 \%$ & $8.7 \%$ \\
\hline Female & $51.2 \%$ & $48.9 \%$ & $36.2 \%$ & $35.4 \%$ & $40.5 \%$ & $33.9 \%$ & $35.0 \%$ & $34.4 \%$ & $31.3 \%$ \\
\hline FRL & $69.0 \%$ & $74.4 \%$ & $81.3 \%$ & $83.1 \%$ & $73.2 \%$ & $88.2 \%$ & $86.7 \%$ & $84.7 \%$ & $92.2 \%$ \\
\hline $\begin{array}{l}\text { LEP } \\
\text { Fraction in Region }\end{array}$ & $7.7 \%$ & $6.6 \%$ & $5.0 \%$ & $4.5 \%$ & $6.0 \%$ & $3.4 \%$ & $7.5 \%$ & $8.7 \%$ & $4.5 \%$ \\
\hline North West Region & & $34.8 \%$ & $22.4 \%$ & $20.0 \%$ & $26.5 \%$ & $12.1 \%$ & $24.6 \%$ & $23.4 \%$ & $9.4 \%$ \\
\hline North East Region & & $20.7 \%$ & $20.4 \%$ & $20.6 \%$ & $16.6 \%$ & $16.1 \%$ & $18.5 \%$ & $14.0 \%$ & $11.6 \%$ \\
\hline Central Region & & $29.0 \%$ & $39.9 \%$ & $42.1 \%$ & $37.9 \%$ & $53.1 \%$ & $40.1 \%$ & $47.7 \%$ & $62.3 \%$ \\
\hline South West Region & & $9.7 \%$ & $9.2 \%$ & $9.3 \%$ & $11.7 \%$ & $13.5 \%$ & $8.9 \%$ & $9.5 \%$ & $12.9 \%$ \\
\hline South East Region & & $5.8 \%$ & $8.2 \%$ & $8.0 \%$ & $7.3 \%$ & $5.2 \%$ & $7.9 \%$ & $5.4 \%$ & $3.7 \%$ \\
\hline
\end{tabular}




\section{Methods}

We use a pooled Probit model to estimate the probability of a student being retained in $9^{\text {th }}$

grade as a function of exclusionary discipline in $8^{\text {th }}$ grade. ${ }^{1}$ Our model is as follows:

$$
\begin{aligned}
\operatorname{Pr}\left(\text { reten }_{i}=1 \mid \boldsymbol{X}\right) & \\
= & \Phi\left(\beta_{0}+\beta_{1} 8 \text { thexcl_disc } c_{i}+\tau 8 \text { th_infract }_{j i}+\beta_{3}{\text { prior_infract }+\beta_{4} \text { prior_reten }}_{i}\right. \\
& \left.+\delta \boldsymbol{X}_{i}+\gamma_{j}+\varepsilon_{i}\right)
\end{aligned}
$$

where 8th excl_disc $i$ is a dummy variable for if student $i$ received any exclusionary discipline in $8^{\text {th }}$ grade. In a separate model, we substitute any exclusionary discipline for the number of days a student was excluded from schools to capture any dosage effect. $\tau 8$ thinfract $_{i}$ is the number of $j$ type infractions student $i$ was written up for in $8^{\text {th }}$ grade. ${ }^{2}$ prior_infract is the total number of infractions student $\mathrm{i}$ had in $8^{\text {th }}$ grade and prior. Prior_reten is a dummy variable if student $i$ was retained in any grades prior to $9^{\text {th }} . X_{i}$ is a vector of student characteristics, including race, FRL status, LEP status, SPED status, and average z-score on $8^{\text {th }}$ grade achievement tests. $\gamma_{j}$ is a

\footnotetext{
${ }^{1}$ We focus on the lasting impact of exclusionary discipline in $8^{\text {th }}$ grade on a $9^{\text {th }}$ grade outcome rather than examining the impact of exclusionary discipline in $9^{\text {th }}$ grade on $9^{\text {th }}$ grade retention for two reasons: first, to test our hypothesis that exclusionary discipline has a long-run impact on student outcomes and does not represent a one-time "shock" from which students can quickly rebound; and, second, because we believe that there could be an underlying external factor that causes the student to act out and become disengaged from school (such as a family trauma) and examining the relationship between the co-occurrence of exclusionary discipline and $9^{\text {th }}$ grade retention could be biased by this third factor. Thus, we focus on a lingering impact of exclusionary discipline to remove potential bias from an unknown confound causing both the behavior and the retention. However, as a robustness check we present estimates from three models examining the relationship between $9^{\text {th }}$ grade exclusionary discipline and $9^{\text {th }}$ grade retention: our preferred Probit specification substituting an indicator of any exclusionary discipline in $9^{\text {th }}$ grade for our indicator of any exclusionary discipline in $8^{\text {th }}$ grade; our preferred Probit specification substituting the number of days excluded in $9^{\text {th }}$ grade for the number of days excluded in $8^{\text {th }}$ grade; and an IV Probit (following our preferred specification) in which we use number of infractions in grades 8 and below to instrument for any exclusionary discipline in $9^{\text {th }}$ grade. These results are available in Appendix A.

${ }^{2}$ We run an alternate specification in which we control for the number of total infractions a student had in all grades 8 and below; those results are consistent (same direction, slightly larger magnitude) with those presented below and are available upon request. We believe controlling for the specific type of infraction is better way of controlling for unobservable characteristics that may impact both the frequency and type of infraction a student commits, and whether or not they are held back in $9^{\text {th }}$ grade. As an additional robustness check, we limit our sample just to students who were written up for a minor non-violent infraction (disorderly conduct, insubordination, truancy, or other infraction) in $8^{\text {th }}$ grade. This more directly addresses whether the use of exclusionary discipline for subjective infractions has persistent negative impacts on student outcomes. Our results are consistent with our main findings, and are presented in Appendix A.
} 
school fixed effect. There are two key parts of our identification strategy. First, we control for the type of behavior. This allows us to capture the effect of exclusionary discipline independent of the student's behavior. Second, we examining only students who switch schools between $8^{\text {th }}$ and $9^{\text {th }}$ grade. Our theory is that students who do not switch schools face a stigma in their school, with teachers and administrators having categorized them as "problem kids", which means they are more likely to be written up for the same behavior that is tolerated in other students. By examining only students who switch schools, we remove this source of bias and get closer to a clean estimate of the impact of exclusionary discipline. We also analyze the relationship for subgroups by race, gender, and FRL status by including interactions between each student characteristic and whether or not the student received exclusionary discipline.

Intuitively, we are comparing two students, each with similar test scores, FRL status, race, and gender. They have the same number and type of infractions in $8^{\text {th }}$ grade, but one student receives exclusionary discipline in $8^{\text {th }}$ grade as a result of the infractions, while the other does not even though he has been written up for the identical infractions. Thus, it is reasonable to argue that the primary difference between these two otherwise similar students is the fact the imposition of exclusionary discipline in grade 8 . We then ask if the academic performance of that student in grade 9 , as measured by his probability of being retained in grade 9 , is worse for the student who received exclusionary discipline than for the student who did not. 


\section{Results}

In this section, we present the results of our analysis, using the methods described above. We begin by asking whether students who receive exclusionary discipline are more likely to be retained than similar students who did not receive exclusionary discipline given a specific infraction history and observable characteristics, then explore whether certain subgroups of students (students of color and students receiving free or reduced price lunch) have differential impacts of such a consequence.

\section{Any Exclusionary Discipline}

We begin by looking at the impact of receiving any exclusionary discipline on the likelihood that a student is retained in $9^{\text {th }}$ grade. We present results from our Probit model, which is our preferred estimator. ${ }^{3}$ Table 4 shows the impact of receiving at least one day of either OSS, ALE, or expulsion in $8^{\text {th }}$ grade on the probability that the student is held back in $9^{\text {th }}$ grade.

\footnotetext{
${ }^{3}$ Results from a linear probability model are consistent with the conclusions reached here; results available upon request.
} 
Table 4: Impact of Any $8^{\text {th }}$ Grade Exclusionary Discipline on Probability of $9^{\text {th }}$ Grade Retention (Probit, Marginal Effects)

Any Exclusionary Discipline, Grade 8

\# of Infractions in $8^{\text {th }}$ Grade, By Type Disorderly Conduct

Insubordination

Truancy

Other Infractions

Alcohol and Other Drugs

Weapons

Violent Infractions

Major Non-violent Infractions

Total \# Infractions, Grade 8 and Below

Any Prior Retention

$8^{\text {th }}$ Grade Standardized Math/ELA Score

Female

Black

Other Student of Color

FRL

SWD

School Effects

Observations

Standard errors clustered at district level
(1)

(2) (3)

$\begin{array}{cccc}0.065^{* * *} & 0.054 * * * & 0.047 * * * & 0.025 * * * \\ (0.020) & (0.017) & (0.015) & (0.009)\end{array}$

$0.015 * *$

$0.015 * *$

$0.014 * *$

$0.014 * * *$

$(0.006)$

$0.017 * * *$

(0.004)

$0.015 * * *$

(0.003)

$0.029 * * *$

(0.010)

(0.010)

$-0.001$

(0.004)

(0.005)

0.014

(0.015)

0.022

(0.015)

$-0.015$

(0.043)

(0.042)

$-0.009$

(0.008)

(0.008)

0.019

(0.028)

(0.028)

$-0.001$

$-0.002$

(0.001)

(0.001)

$0.052 * *$

$0.041 * *$

(0.019)

$-0.103^{* * *}$

(0.011)

(0.006)

$0.016^{* * *}$

(0.004)

(0.003)

$0.011 * * *$

(0.003)

0.030 ***

$0.022 * * *$

(0.009)

(0.008)

$-0.001$

$-0.002$

(0.004)

(0.004)

$0.028 *$

(0.015)

$-0.017$

$0.043^{* * *}$

(0.015)

(0.045)

0.015

(0.047)

$-0.005$

0.001

(0.007)

(0.005)

(0.020)

0.024

0.022

(0.031)

(0.027)

$-0.002$

$-0.001$

(0.001)

$0.035 * *$

(0.001)

$0.029 * *$

(0.018)

$-0.114 * * *$

(0.014)

$-0.121 * * *$

(0.011)

$-0.023 * * *$

(0.004)

(0.007)

0.023

$-0.032 * * *$

(0.007)

(0.015)

$0.054 * * *$

$-0.020 * *$

(0.015)

$0.027 * *$

(0.011)

$-0.111 * * *$

(0.009)

0.004

(0.009)

$0.040 * * *$

(0.013)

(0.011)

$-0.123 * * *$

(0.010)

$\begin{array}{lll}\text { No No } & \text { No } & \text { Yes }\end{array}$

24,089

20,848

20,843

18,660 
Column (1) of Table 4 shows the estimated impact of receiving exclusionary discipline in $8^{\text {th }}$ grade on the likelihood that a student is retained in $9^{\text {th }}$ grade after only controlling for the student's past actions, but without controlling for student or school characteristics. This naïve specification indicates that students who face exclusionary discipline in $8^{\text {th }}$ grade are 6.5 percentage points more likely to be retained in $9^{\text {th }}$ grade than students who did not face exclusionary discipline. We see that each additional infraction for disorderly conduct, insubordination, or truancy is associated with an increased likelihood of retention $(1.5,1.7$, and 3.1 percentage points, respectively), while each recorded incidence of violent infractions is associated with a decreased likelihood of retention in $9^{\text {th }}$ grade ( 1 percentage points); however, category for other infractions has no significant relationship with whether or not a student is retained in $9^{\text {th }}$ grade. The coefficients on disorderly conduct, insubordination, and truancy indicate that our outcome is indeed related to students' observable non-cognitive skills, such as self-management, that may also be related to classroom behavior. The negative coefficient on staff assault indicates that teachers may have some subjectivity in deciding whether or not to retain a student, and may be less likely to retain a student they do not want to have in their class again next year. Finally, we see in column (1) that students who have previously been retained (in $8^{\text {th }}$ grade or before) are significantly more likely (5.2 percentage points) to be retained in $9^{\text {th }}$ grade than students who have progressed normally.

In column (2) of Table 4, we add in each student's lagged average standardized Math and ELA score on statewide assessments to control for past achievement and unobservable characteristics that contribute to achievement. As expected, there is a strong relationship between a student's academic achievement and the likelihood that a student will be retained. A one standard deviation increase in achievement in $8^{\text {th }}$ grade is associated with a 10.3 percentage point 
decrease in the probability that a student will be retained in $9^{\text {th }}$ grade. Once we control for this other important predictor of retention, our variable of interest - whether the student faced exclusionary discipline in $8^{\text {th }}$ grade - decreases in magnitude, but remains highly significant and substantial in magnitude: receiving at least one day of exclusionary discipline in $8^{\text {th }}$ grade is associated with a 5.4 percentage point increase in the likelihood of being retained in $9^{\text {th }}$ grade.

In column (3) of Table 4, we add controls for observable student characteristics-gender, race, free or reduced price lunch status, and special education status. These characteristics in general have predictive power when looking at the likelihood that a student will be held back in $9^{\text {th }}$ grade; interestingly, however, the likelihood that black students are held back in $9^{\text {th }}$ grade is indistinguishable from the likelihood that white students are held back in $9^{\text {th }}$ grade after controlling for infraction, consequence, and retention history, as well as past achievement, FRL status, and special education status. Past achievement continues to have the largest predictive power when looking at the likelihood that a student will be held back in $9^{\text {th }}$ grade - a one standard deviation increase in achievement in $8^{\text {th }}$ grade is associated with an 11.4 percentage point decrease in the likelihood that a student will be retained in $9^{\text {th }}$ grade. Having been retained in a prior year increases the likelihood that a student will be retained in $9^{\text {th }}$ grade by 3.5 percentage points. Our variable of interest—facing exclusionary discipline in $8^{\text {th }}$ grade — remains highly significant and substantial. Receiving at least one day of OSS, ALE, or expulsion is associated with a 4.7 percentage point increase in the likelihood that a student is retained in $9^{\text {th }}$ grade, after taking into account infraction, retention, and achievement history, as well as observable student characteristics.

In columns (1) through (3), we exploit variation between students who faced and did not face exclusionary discipline in $8^{\text {th }}$ grade, but we do not control for school-level characteristics 
that may impact the likelihood that a student is held back in $9^{\text {th }}$ grade. Principals, teachers, and even parents have some discretion in determining whether or not a student is promoted to the next grade, and school culture is thus important to take into account when predicting the likelihood that a student will be retained. In column (4), we include school fixed effects to account for these between-school differences. In this specification, we only look at the impact of exclusionary discipline on the likelihood that a student is retained as compared to a student who did not receive exclusionary discipline in $8^{\text {th }}$ grade and attended the same school in $9^{\text {th }}$ grade. This is our preferred specification, as we are able to control both for student observed characteristics, unobserved characteristics captured in measures of past achievement, and school characteristics that likelihood of retention independent of student characteristics. The decrease in observations in column (4) reflects the necessity of controlling for school: some schools retained no students in the years examined, and students who attended those schools $(2,183)$ were not included in the estimation.

In our preferred specification, receiving at least one day of exclusionary discipline in $8^{\text {th }}$ grade is associated with a 2.5 percentage point increase in the likelihood that a student will be retained in $9^{\text {th }}$ grade. Having been retained in a prior year is also significant, and is associated with a 2.9 percentage point increase in the likelihood that a student will be retained in $9^{\text {th }}$ grade. Past academic achievement is the most substantive protective characteristic against retention-a one standard deviation in achievement in $8^{\text {th }}$ grade is associated with a 12.1 percentage point decrease in the likelihood that a student will be retained in $9^{\text {th }}$ grade. Females are 3.2 percentage points less likely than males to be retained in $9^{\text {th }}$ grade. Interestingly, while we find no statistically significant difference in the likelihood of being retained between black and white students between schools (shown in column 3), black students are 2 percentage points less likely 
to be retained than white students who attend the same school. There is no difference in the likelihood of retention between non-black students of color and white students within the same school. Students receiving free or reduced price lunch for at least one full year during 2008-09 to 2014-15 were 4.0 percentage points more likely to be retained in $9^{\text {th }}$ grade than students who never received FRL. Finally, students with disabilities were 12.3 percentage points less likely to be retained than students without disabilities who attended the same school for their $9^{\text {th }}$ grade year.

\section{Days of Exclusionary Discipline}

Above, we focused on the impact of ever facing exclusionary discipline in $8^{\text {th }}$ grade on the probability of being retained in $9^{\text {th }}$ grade. Here, we expand our variable of interest into four categories for the number of days (1-5 days, 6-10 days, 11-15 days, and 16 or more days) a student was suspended, expelled, or in an ALE during $8^{\text {th }}$ grade. Our outcome is still the probability of being retained in $9^{\text {th }}$ grade. Table 5 presents the results of this analysis with and without controlling for school effects. 
Table 5: Impact of a Day of Exclusionary Discipline on Probability of $9^{\text {th }}$ Grade Retention (Probit, Marginal Effects)

\begin{tabular}{|c|c|c|}
\hline & $(1)$ & $(2)$ \\
\hline 1-5 Days Excluded, Grade 8 & $\begin{array}{c}0.036 * * * \\
(0.013)\end{array}$ & $\begin{array}{l}0.017 * \\
(0.009)\end{array}$ \\
\hline 6-10 Days Excluded, Grade 8 & $\begin{array}{c}0.067 * * * \\
(0.018)\end{array}$ & $\begin{array}{c}0.041 * * * \\
(0.014)\end{array}$ \\
\hline 11-15 Days Excluded, Grade 8 & $\begin{array}{c}0.097 * * * \\
(0.024)\end{array}$ & $\begin{array}{c}0.063 * * * \\
(0.018)\end{array}$ \\
\hline 16+ Days Excluded, Grade 8 & $\begin{array}{c}0.083 * * \\
(0.033)\end{array}$ & $\begin{array}{c}0.040 \\
(0.026)\end{array}$ \\
\hline $\begin{array}{l}\text { \# of Infractions in } 8^{\text {th }} \text { Grade, By Type } \\
\text { Disorderly Conduct }\end{array}$ & $\begin{array}{l}0.011 * \\
(0.006)\end{array}$ & $\begin{array}{c}0.012 * * * \\
(0.005)\end{array}$ \\
\hline Insubordination & $\begin{array}{c}0.016^{* * * *} \\
(0.003)\end{array}$ & $\begin{array}{c}0.010 * * * \\
(0.002)\end{array}$ \\
\hline Truancy & $\begin{array}{c}0.030 * * * \\
(0.009)\end{array}$ & $\begin{array}{c}0.022 * * * \\
(0.008)\end{array}$ \\
\hline Other Infraction & $\begin{array}{l}-0.003 \\
(0.003)\end{array}$ & $\begin{array}{l}-0.002 \\
(0.003)\end{array}$ \\
\hline Alcohol and Other Drugs & $\begin{array}{c}0.021 \\
(0.016)\end{array}$ & $\begin{array}{c}0.038 * * \\
(0.016)\end{array}$ \\
\hline Weapons & $\begin{array}{l}-0.026 \\
(0.047)\end{array}$ & $\begin{array}{c}0.008 \\
(0.049)\end{array}$ \\
\hline Violent Infractions & $\begin{array}{l}-0.008 \\
(0.007)\end{array}$ & $\begin{array}{l}-0.002 \\
(0.006)\end{array}$ \\
\hline Major Nonviolent Infractions & $\begin{array}{c}0.017 \\
(0.034)\end{array}$ & $\begin{array}{c}0.017 \\
(0.029)\end{array}$ \\
\hline Total Infractions, Grades 8 and Below & $\begin{array}{l}-0.002 \\
(0.001)\end{array}$ & $\begin{array}{l}-0.001 \\
(0.001)\end{array}$ \\
\hline Any Prior Retention & $\begin{array}{c}0.033^{*} \\
(0.018)\end{array}$ & $\begin{array}{c}0.029 * * \\
(0.015)\end{array}$ \\
\hline Standardized $8^{\text {th }}$ Grade Math/ELA Score & $\begin{array}{c}-0.114 * * * \\
(0.011)\end{array}$ & $\begin{array}{c}-0.121 * * * \\
(0.004)\end{array}$ \\
\hline Student Characteristics & Yes & Yes \\
\hline School Effects & No & Yes \\
\hline Observations & 20,843 & 18,660 \\
\hline
\end{tabular}


In column (1), 1-5 days of exclusionary discipline in $8^{\text {th }}$ grade is associated with a 3.6 percentage point increase in the likelihood of being retained in $9^{\text {th }}$ grade. The coefficient magnitudes increases with the number of days of exclusionary discipline. Six to ten days of exclusionary discipline is associated with a 6.7 percentage point increase, 11-15 days is associated with a 9.7 percentage point increase, and 16 or more days is associated with a 8.3 percentage point increase in the likelihood of being retained in $9^{\text {th }}$ grade. Consistent with what we saw in Table 4, having been retained in a prior grade is also a risk factor for being retained in $9^{\text {th }}$ grade (having been retained is associated with a 3.3 percentage point increase in the likelihood of retention), while higher academic achievement is a substantial protective factor (a one standard deviation in achievement is associated with an 11.4 percentage point decrease in the likelihood of retention). By controlling for the number and type of infractions in $8^{\text {th }}$ grade, we are also controlling for unobservable student characteristics that may make a student more or less likely to infract, which is an important consideration if we want an unbiased estimate of the impact of exclusionary discipline relative to non-exclusionary discipline on students with the same history of infractions. We again see that each incidence of disorderly conduct, insubordination, and truancy increases the student's likelihood of $9^{\text {th }}$ grade retention. Estimates of the relationships between observable student characteristics and the likelihood of being retained in $9^{\text {th }}$ grade are generally similar to those estimated in Table 4.

Column (2) presents the results of our preferred specification, which includes school fixed effects, so we are comparing students to their peers within the same school in $9^{\text {th }}$ grade. Consistent with column (1), 1-5 days of exclusionary discipline in $8^{\text {th }}$ grade is associated with a 1.7 percentage point increase in the likelihood that a student is retained in $9^{\text {th }}$ grade. Six to ten days of exclusionary discipline is associated with a 4.1 percentage point increase, and 11-15 days 
is associated with a 6.3 percentage point increase likelihood of being retained in $9^{\text {th }}$ grade.

Interestingly students who received 16 or more days of exclusionary discipline are not statistically more likely to be retained. This suggests that there is significant variation in school policies or implementation that explain the relationship between exclusionary discipline and retention within schools. Estimates of other observable student characteristics remain consistent with what was seen in Table 4, when we looked at whether a student faced any exclusionary discipline.

\section{Subgroup Analyses}

Our final analysis looks for differential impacts of exclusionary discipline on particular groups of students. We hypothesized that more disadvantaged students would be more hurt by exclusionary discipline, as they may be less likely to make up for missed class time or already at risk of feeling marginalized and unwelcome in their school environment, both of which could put students at risk of disengagement, retention, and eventually drop out. Table 6 test this hypothesis with respect to students of color, female students, and students receiving free or reduced price lunch. Importantly, we are again controlling for the number and type of infractions in grade 8 , and unobservable student characteristics that might make students more or less prone to retention. 
Table 6: Differential Impact of Any $8^{\text {th }}$ Grade Exclusionary Discipline on Probability of $9^{\text {th }}$ Grade Retention (Probit, Marginal Effects)

\begin{tabular}{|c|c|c|c|c|c|c|}
\hline & $\begin{array}{c}(1) \\
\text { Gender }\end{array}$ & $\begin{array}{c}(2) \\
\text { Gender } \\
\end{array}$ & $\begin{array}{c}(3) \\
\text { Race } \\
\end{array}$ & $\begin{array}{c}(4) \\
\text { Race }\end{array}$ & $\begin{array}{c}(5) \\
\text { Income }\end{array}$ & $\begin{array}{c}(6) \\
\text { Income }\end{array}$ \\
\hline Male*Exclusionary Discipline & $\begin{array}{l}-0.012 \\
(0.014)\end{array}$ & $\begin{array}{c}0.020 * * \\
(0.010)\end{array}$ & & & & \\
\hline Female*Exclusionary Discipline & & $\begin{array}{r}0.033 * * \\
(0.013)\end{array}$ & & & & \\
\hline Black*Exclusionary Discipline & & & $\begin{array}{c}-0.014 \\
(0.011)\end{array}$ & $\begin{array}{c}0.022 * * \\
(0.009)\end{array}$ & & \\
\hline Latino/a*Exclusionary Discipline & & & $\begin{array}{l}-0.029 \\
(0.029)\end{array}$ & $\begin{array}{c}0.007 \\
(0.032)\end{array}$ & & \\
\hline Other Student of Color*Exclusionary & & & $\begin{array}{c}-0.025 \\
(0.049)\end{array}$ & $\begin{array}{c}0.011 \\
(0.049)\end{array}$ & & \\
\hline White*Exclusionary Discipline & & & & $\begin{array}{c}0.036 * * * \\
(0.012)\end{array}$ & & \\
\hline FRL*Exclusionary Discipline & & & & & $\begin{array}{c}-0.040 * * \\
(0.016)\end{array}$ & $\begin{array}{c}0.013 \\
(0.010)\end{array}$ \\
\hline Non-FRL*Exclusionary Discipline & & & & & & $\begin{array}{c}0.020 \\
(0.020)\end{array}$ \\
\hline Any Exclusionary Discipline, $8^{\text {th }}$ Grade & $\begin{array}{r}0.033 * * \\
(0.013)\end{array}$ & & $\begin{array}{c}0.036 * * * \\
(0.012)\end{array}$ & & $\begin{array}{c}0.057 * * * \\
(0.016)\end{array}$ & \\
\hline Black & $\begin{array}{c}-0.020 * * \\
(0.009)\end{array}$ & $\begin{array}{c}-0.020 * * \\
(0.009)\end{array}$ & $\begin{array}{c}-0.018 * \\
(0.010)\end{array}$ & $\begin{array}{c}-0.018 * \\
(0.010)\end{array}$ & $\begin{array}{c}-0.020 * * \\
(0.009)\end{array}$ & $\begin{array}{c}-0.020 * * \\
(0.009)\end{array}$ \\
\hline Hispanic & $\begin{array}{l}-0.001 \\
(0.010)\end{array}$ & $\begin{array}{l}-0.001 \\
(0.010)\end{array}$ & $\begin{array}{c}0.003 \\
(0.010)\end{array}$ & $\begin{array}{c}0.003 \\
(0.010)\end{array}$ & $\begin{array}{c}-0.001 \\
(0.009)\end{array}$ & $\begin{array}{c}-0.001 \\
(0.010)\end{array}$ \\
\hline Other Student of Color & $\begin{array}{c}0.018 \\
(0.014)\end{array}$ & $\begin{array}{c}0.018 \\
(0.014)\end{array}$ & $\begin{array}{c}0.022 \\
(0.014)\end{array}$ & $\begin{array}{c}0.022 \\
(0.014)\end{array}$ & $\begin{array}{c}0.018 \\
(0.014)\end{array}$ & $\begin{array}{c}0.018 \\
(0.014)\end{array}$ \\
\hline Any Prior Retention, Grades 8 or Below & $\begin{array}{c}0.030 * * \\
(0.014)\end{array}$ & $\begin{array}{c}0.030 * * \\
(0.014)\end{array}$ & $\begin{array}{c}0.030 * * \\
(0.014)\end{array}$ & $\begin{array}{r}0.030 * * \\
(0.014)\end{array}$ & $\begin{array}{r}0.029 * * \\
(0.014)\end{array}$ & $\begin{array}{c}0.030 * * \\
(0.014)\end{array}$ \\
\hline Female & $\begin{array}{c}-0.035^{* * *} \\
(0.007)\end{array}$ & $\begin{array}{c}-0.035^{* * *} \\
(0.007)\end{array}$ & $\begin{array}{c}-0.032 * * * \\
(0.007)\end{array}$ & $\begin{array}{c}-0.032 * * * \\
(0.007)\end{array}$ & $\begin{array}{c}-0.032 * * * \\
(0.007)\end{array}$ & $\begin{array}{c}-0.032 * * * \\
(0.007)\end{array}$ \\
\hline Standarized $8^{\text {th }}$ Grade Math/ELA Score & $\begin{array}{c}-0.121 * * * \\
(0.004)\end{array}$ & $\begin{array}{c}-0.121 * * * \\
(0.004)\end{array}$ & $\begin{array}{c}-0.121 * * * \\
(0.004)\end{array}$ & $\begin{array}{c}-0.121 * * * \\
(0.004)\end{array}$ & $\begin{array}{c}-0.121 * * * \\
(0.004)\end{array}$ & $\begin{array}{c}-0.121 * * * \\
(0.004)\end{array}$ \\
\hline FRL & $\begin{array}{c}0.040 * * * \\
(0.011)\end{array}$ & $\begin{array}{c}0.040 * * * \\
(0.011)\end{array}$ & $\begin{array}{c}0.040 * * * \\
(0.011)\end{array}$ & $\begin{array}{c}0.040 * * * \\
(0.011)\end{array}$ & $\begin{array}{c}0.046 * * * \\
(0.011)\end{array}$ & $\begin{array}{c}0.041 * * * \\
(0.012)\end{array}$ \\
\hline SWD & $\begin{array}{c}-0.123 * * * \\
(0.010)\end{array}$ & $\begin{array}{c}-0.123 * * * \\
(0.010)\end{array}$ & $\begin{array}{c}-0.123 * * * \\
(0.010)\end{array}$ & $\begin{array}{c}-0.123 * * * \\
(0.010)\end{array}$ & $\begin{array}{c}-0.123 * * * \\
(0.010)\end{array}$ & $\begin{array}{c}-0.123 * * * \\
(0.010)\end{array}$ \\
\hline \# of Infractions in $8^{\text {th }}$ Grade, by Type & Yes & Yes & Yes & Yes & Yes & Yes \\
\hline Total \# of Infractions, Grades 8 and Below & Yes & Yes & Yes & Yes & Yes & Yes \\
\hline School Effects & Yes & Yes & Yes & Yes & Yes & Yes \\
\hline Observations & 18,643 & 18,643 & 18,643 & 18,643 & 18,643 & 18,643 \\
\hline
\end{tabular}


Columns (1) and (2) tests the hypothesis that male and female students are differentially impacted by exclusionary discipline; however, we find no evidence that this is the case. In column (2), we see that facing exclusionary discipline in $8^{\text {th }}$ grade is associated with a 2 percentage point increase in the likelihood of $9^{\text {th }}$ grade retention for male students and a 3.3 percentage point increase in the likelihood of retention for female students; however, these estimates are not distinguishable from each other (column 1). Consistent with what we have seen in prior models, having been retained in $8^{\text {th }}$ grade or below is a major risk factor for $9^{\text {th }}$ grade retention, while increased achievement in $8^{\text {th }}$ grade is a substantial protective factor against $9^{\text {th }}$ grade retention.

Columns (3) and (4) explore the differential impact of exclusionary discipline on students of different racial backgrounds. The coefficients can be interpreted as the impact of exclusionary discipline on the likelihood of retention given their race. We see in column (4) that for black students, receiving any exclusionary discipline in $8^{\text {th }}$ grade is associated with a 2.2 percentage point increase in the likelihood of being retained in $9^{\text {th }}$ grade, while for Latino/a students and other students of color receiving any exclusionary discipline in $8^{\text {th }}$ grade is not significantly associated the likelihood of being retained in $9^{\text {th }}$ grade. Interestingly, this effect is larger for white students: any exclusionary discipline is associated with a 3.6 percentage point increase in the likelihood of being retained in $9^{\text {th }}$ grade. However, we see in column (3) that these differences are not statistically significant: the attenuated impact of exclusionary discipline for students of color is not significantly different from the baseline impact of exclusionary discipline for white students. Any prior retention remains a significant and substantial risk factor for $9^{\text {th }}$ grade retention, while $8^{\text {th }}$ grade achievement is a significant and substantial protective factor. Columns (5) and (6) tests the hypothesis that FRL students face disparate impacts of 
exclusionary discipline, but we do not find consistent evidence that this is the case. In column (6) we see that when we break out students by FRL status, we see no significant relationship between exclusionary discipline and retention. However, in column (5) we see a significant relationship between exclusionary discipline and retention, but that receiving FRL slightly attenuates the effect of exclusionary discipline relative to the impact on non-FRL students. We discuss this at greater length in the next session. As before, academic achievement is the largest protective factor against retention, while being retained in a younger grade remains a significant and substantial risk factor.

\section{Discussion and Policy Implications}

At the beginning of this paper, we hypothesized that receiving exclusionary discipline in $8^{\text {th }}$ grade would make students more likely to be retained in $9^{\text {th }}$ grade. Our proposed underlying mechanism was that students who faced out-of-school suspension, expulsion, or placement in an alternative learning environment would act as a signal to students, indicating that they were unfit or unwelcomed in the regular school environment. This perceived marginalization would lead students to become disengaged in classes, eroding both their academic achievement and required soft skills, such as showing up to class on time, completing work, and engaging in classroom tasks. This behavior would result in retention. In this paper, we have attempted to test this hypothesis.

Our first challenge to identification was disentangling the impact of teacher perceptions of a student as a "troublemaker" or a "hopeless case" as a result of past infractions. It could be that if a teacher perceives a student as a problem, they will be less likely to reach out help that student academically, and more likely to punish or hold back the student. To address this, we 
limited our sample just to students who switch schools between $8^{\text {th }}$ and $9^{\text {th }}$ grade. Thus, the students in our sample have a clean slate with their $9^{\text {th }}$ grade teachers, and our estimated impacts of exclusionary discipline should not be related to teachers' attitudes towards students. We also included school fixed effects, in order to account for time-invariant unobservable school characteristics that impact the likelihood that a student is held back in $9^{\text {th }}$ grade. It could be that some high school principals are more reluctant to retain students than others; if so, failing to include school fixed effects would bias our results. Finally, we controlled for observable student characteristics, including race, gender, free or reduced price lunch status, Special Education services, prior achievement, and prior retention. By controlling for these characteristics, we are separating out the impact of the intervention - exclusionary discipline-from other factors that may impact the likelihood that a student is retained in $9^{\text {th }}$ grade.

\section{Main Results}

When we included our full set of controls, we found that students who faced exclusionary discipline in $8^{\text {th }}$ grade were 2.5 percentage points more likely to be retained in $9^{\text {th }}$ grade than students who were not excluded. This is, after we control for the number and type of infractions each student received in $8^{\text {th }}$ grade (so we are comparing students who infracted and did not face exclusionary discipline to students who infracted the same number of times but were excluded from the school environment), we still find a significant relationship between exclusionary discipline and $9^{\text {th }}$ grade retention. We also found a strong relationship between the number of days students receives exclusionary discipline and their likelihood of being retained in $9^{\text {th }}$ grade. The relationship varied from a 1.7 percentage point increased likelihood for student who received 1-5 days of exclusionary discipline to 6.3 percentage point increased for student who 
were excluded for 11-15 days. There was no statistically significant increased probability of retention for students who received 16 or more days when including school fixed effects. All other results were significant at the $95 \%$ confidence level, and were robust across model specifications. This suggests that the use of exclusionary discipline in middle school has persistent, negative impacts on the probability of students being retained in $9^{\text {th }}$ grade.

\section{Subgroup Analyses}

We initially hypothesized that disadvantaged students (students of color, low income students, and male students) would be more strongly impacted by exclusionary discipline than advantaged students. We theorized that more advantaged students would have greater support systems than disadvantaged students, which would make them more resilient to adverse events, such as exclusionary discipline, thus ameliorating the impact of facing OSS, expulsion, or ALE. However, our results did not support this hypothesis. Instead, we found that the impact of exclusionary discipline was significantly less for disadvantaged students than for advantaged students. We found that while exclusionary discipline resulted in a 3.6 percentage point increase in the likelihood of retention for white students, exclusionary discipline resulted in a 2.2 percentage point increase in the likelihood of retention for black students; however, we found no evidence that these impacts were significantly different from each other. We also found that black student and Latino/a students who were not excluded were less likely to be retained than white students who were not excluded. While these results initially seemed counterintuitive, and certainly ran counter to our stated hypothesis, we believe they may indicate the presence of different expectations of behavior and achievement for students of different backgrounds.

If teachers hold the highest expectations for advantaged students, and believe 
(consciously or unconsciously) that disadvantaged students can only meet lower standards of conduct and achievement, then we can reasonably expect teachers' responses to the same behaviors by different students to vary. Let us imagine a white student and a black student who both face exclusionary discipline in $8^{\text {th }}$ grade. Both feel marginalized and unwelcomed at school as a result, and in $9^{\text {th }}$ grade both refuse to complete their classwork and instead sit in the back of the room and try to avoid the teacher. If the teacher on some level believes that the white student is capable of more, but the black student is not, the teacher has a reason to retain the white student but not the black student. From the teacher's perspective, she is helping both students: the white student will learn more and catch up to her peers if she is retained, while the black student will not get more out of $9^{\text {th }}$ grade regardless of how much time she spends in the grade. Thus, the teacher believes retaining the black student is academically pointless and punitive. The same behavior, prompted by the same initial cause of exclusionary discipline in $8^{\text {th }}$ grade, leads to two different outcomes for the black and white students and different probabilities of retention, on average, across the two groups. Analogous logic holds for our results concerning FRL students, and for male versus female students.

\section{Policy Implications and Future Research}

Our results suggest two areas of concern: first, that exclusionary discipline has persistent negative impacts on student outcomes; and, second, that the impacts of exclusionary discipline could be mediated by teachers' attitudes towards students based on student backgrounds. The first result is consistent with current efforts by states and districts to limit the use of exclusionary discipline in order to improve student outcomes. A line of future research would be to explore our proposed mechanism through which exclusionary discipline leads to a higher likelihood of 
retention by looking at intermediate outcomes such as tardiness, absenteeism, or incomplete coursework following exclusionary discipline. Such research would require detailed school-level administrative records, but would provide further information to schools on how to intervene with students who have faced exclusionary discipline in order to prevent the adverse impacts of exclusionary discipline. It may be that schools do not want to completely rule out the possibility of exclusionary discipline as a consequence, but do want to create interventions to facilitate student re-entry to school after OSS, ALE, or expulsion in a way that will not lead to further disengagement from school.

The second policy implication, arising from the results in our subgroup analyses, indicates that is important for teachers, during their preparation and ongoing professional development, to examine their mindsets about student ability and to reflect upon on their classroom practices and how they may inadvertently differentially affect different groups of students. This is not a straightforward policy lever for school leaders of policymakers, but it is nevertheless important for ensuring that all students are given the opportunity to thrive in a supportive school environment.

\section{Conclusion}

In this paper, we have shown that exclusionary discipline has persistent and meaningful negative impacts on student outcomes. Specifically, we have shown that facing any exclusionary discipline in $8^{\text {th }}$ grade increases the likelihood that a student will be held back in $9^{\text {th }}$ grade by 2.5 percentage points independent of the student's schools, his or her recorded behavior, and other observable characteristics including academic achievement. Further, we find that a student's probability of being retained increases when they receive more days of exclusionary discipline. 
We recommend that schools continue to cautiously use of exclusionary discipline and explore interventions that help students reintegrate into the school community after facing such a consequence in order to ameliorate the adverse effects of OSS, ALE, and expulsion. We further recommend ongoing development and reflection on the part of teachers to ensure that high expectations are held for all students.

\section{References}

Anderson, Kaitlin, and Gary Ritter. 2015. Discipline Disproportionalities in Schools: The Relationship between Student Characteristics and School Disciplinary Outcomes. EDRE Working Paper 2015-08.

Beck, Audrey N. and Clara G. Muschkin. 2012. The Enduring Impact of Race: Understanding Disparities in Student Disciplinary Infractions and Achievement. Sociological Perspectives 55 (4): 637-662.

Greene, Jay P., and Marcus A. Winters. 2007. Revisiting Grade Retention: An evaluation of Florida's test-based promotion policy. Education Finance and Policy 2 no. 4 (Fall): 319340.

Jacob, Brian A., and Lars Lefgren. 2002. Remedial Education and Student Achievement: A regression-discontinuity analysis. NBER working paper \# 8918.

Jacob, Brian A., and Lars Lefgren. 2009. The Effect of Grade Retention on High School Completion. American Economic Journal: Applied Economics 1 no. 3 (July): 33-58.

Jimerson, Shane R. 1999. On the Failure of Failure: Examining the association between early grade retention and education and employment outcomes during late adolescence. Journal of School Psychology 37 no.3: 243-272.

Jimerson, Shane R. 2001. A Synthesis of Grade Retention Research: Looking backward and moving forward. The California School Psychologist 6:47-59

Jimerson, Shane R., Gabrielle E. Anderson, and Angela D. Whipple. 2002. Winning the Battle and Losing the War: Examining the relation between grade retention and dropping out of high school. Psychology in Schools 39 (4): 441-457

Losen, Daniel, Cheri Hodson, Michael A. Keith II, Katrina Morrison, and Shakti Belway. 2015. Are We Closing the School Discipline Gap? The Center for Civil Rights Remedies.

Losen, Daniel J., and Russell J. Skiba. 2010. Suspended Education Urban Middle Schools in Crisis. Southern Poverty Law Center.

Noltemeyer, Amity L., and Rose Marie Ward. 2015. Relationship between School Suspension and Student Outcomes: A meta-analysis. School Psychology Review 44 no. 2: 224-240.

Muschkin, Clara G., Elizabeth Glennie, and Audrey N. Beck. 2014. Peer Context: Do old for grade and retained peers influence student behavior in middle school? Teachers College Record 116 (April): 1-37. 
Ozek, Umut. 2015. Hold Back to Move Forward? Early Grade Retention and Student Misbehavior. Education Finance and Policy 10 no. 3 (Summer): 350-377.

Raffaele Mendez, Linda M. 2003. Predictors of suspension and negative school outcomes: A longitudinal investigation. New Directions for Youth Development no. 99 (Fall):17-33.

Raffaele Mendez, Linda M., Howard M. Knoff, and John M. Ferron. 2002. School Demographic Variables and Out-of-School Suspension Rates: A quantitative and Qualitative Analysis of a Large, Ethnically diverse school District. Psychology in the Schools 39(3): 259-277.

Schwerdt, Guido, and Martin R. West. 2012. The Effects of Early Grade Retention on Student Outcomes over Time: Regression Discontinuity Evidence from Florida. Program on Education Policy and Governance Working Paper Series. PEPG 12-09.

Silberglitt, Benjamin, James J. Appleton, Matthew K. Burns, and Shane R. Jimerson. 2006.

Examining the effects of grade retention on student reading performance: A longitudinal study. Journal of School Psychology 44 (May): 255-270.

Skiba, Russell J. 2014. The Failure of Zero Tolerance. Reclaiming Children and Youth Journal 22 no.4 (Winter): 27-33. 


\section{Appendix A: Relationship Between $9^{\text {th }}$ Grade Exclusionary Discipline and $9^{\text {th }}$ Grade Retention}

Table A1: Impact of $9^{\text {th }}$ Grade Discipline on Likelihood of $9^{\text {th }}$ Grade Retention (Probit, Marginal Effects)

\begin{tabular}{|c|c|c|c|}
\hline & $\begin{array}{c}(1) \\
\text { Any } \\
\end{array}$ & $\begin{array}{c}(2) \\
\text { Days }\end{array}$ & $\begin{array}{c}(3) \\
\text { IV-Any } \\
\end{array}$ \\
\hline Any Exclusionary Discipline, $9^{\text {th }}$ Grade & $\begin{array}{c}0.093 * * * \\
(0.010)\end{array}$ & & $\begin{array}{c}1.965^{* * *} * \\
(0.190)\end{array}$ \\
\hline Days Excluded, $9^{\text {th }}$ Grade & & $\begin{array}{c}0.006 * * * \\
(0.001)\end{array}$ & \\
\hline Prior Retention, $8^{\text {th }}$ Grade or Below & $\begin{array}{c}0.020 \\
(0.013)\end{array}$ & $\begin{array}{c}0.013 \\
(0.013)\end{array}$ & $\begin{array}{c}0.032 \\
(0.070)\end{array}$ \\
\hline \multicolumn{4}{|l|}{ \# of $8^{\text {th }}$ Grade Infractions, By Type } \\
\hline Alcohol & $\begin{array}{c}0.059 \\
(0.047)\end{array}$ & $\begin{array}{c}0.048 \\
(0.045)\end{array}$ & \\
\hline Bullying & $\begin{array}{c}0.002 \\
(0.009)\end{array}$ & $\begin{array}{l}-0.005 \\
(0.011)\end{array}$ & \\
\hline Disorderly Conduct & $\begin{array}{c}0.011 * * * \\
(0.003)\end{array}$ & $\begin{array}{c}0.003 \\
(0.003)\end{array}$ & \\
\hline Drugs & $\begin{array}{c}0.054 * * \\
(0.027)\end{array}$ & $\begin{array}{l}0.046^{*} \\
(0.025)\end{array}$ & \\
\hline Explosives & $\begin{array}{l}-0.124 \\
(0.151)\end{array}$ & $\begin{array}{c}-0.613 * * * \\
(0.135)\end{array}$ & \\
\hline Fighting & $\begin{array}{c}0.000 \\
(0.006)\end{array}$ & $\begin{array}{l}-0.003 \\
(0.007)\end{array}$ & \\
\hline Gangs & $\begin{array}{c}0.014 \\
(0.031)\end{array}$ & $\begin{array}{c}0.000 \\
(0.030)\end{array}$ & \\
\hline Guns & $\begin{array}{c}0.105 \\
(0.078)\end{array}$ & $\begin{array}{c}0.088 \\
(0.078)\end{array}$ & \\
\hline Insubordination & $\begin{array}{c}0.007 * * * \\
(0.002)\end{array}$ & $\begin{array}{c}0.003 \\
(0.003)\end{array}$ & \\
\hline Knife & $\begin{array}{c}0.026 \\
(0.055)\end{array}$ & $\begin{array}{c}0.003 \\
(0.051)\end{array}$ & \\
\hline Other Infraction & $\begin{array}{l}-0.003 \\
(0.004)\end{array}$ & $\begin{array}{l}-0.004 \\
(0.003)\end{array}$ & \\
\hline Staff Assault & $\begin{array}{l}-0.035 \\
(0.058)\end{array}$ & $\begin{array}{c}-0.043 \\
(0.066)\end{array}$ & \\
\hline Student Assault & $\begin{array}{l}-0.006 \\
(0.029)\end{array}$ & $\begin{array}{c}-0.001 \\
(0.027)\end{array}$ & \\
\hline Tobacco & 0.034 & 0.028 & \\
\hline
\end{tabular}

\footnotetext{
${ }^{4}$ Any exclusionary discipline in $9^{\text {th }}$ grade is instrumented using the number of each type of infraction the student was recorded for in $8^{\text {th }}$ grade. Total infractions in $8^{\text {th }}$ grade and below are included in the second stage to control for unobservable characteristics that may contribute to both infractions and retention.
} 


$\begin{array}{ccc} & (0.021) & (0.019) \\ \text { Truancy } & 0.019 * * * & 0.022 * * \\ & (0.007) & (0.009) \\ \text { Vandalism } & 0.021 & 0.009 \\ & (0.030) & (0.027)\end{array}$

Total Infractions, Grades 8 and Below

\begin{tabular}{|c|c|c|c|}
\hline Total Infractions, Grades 8 and Below & & & $\begin{array}{c}-0.019 * * * \\
(0.004)\end{array}$ \\
\hline Standardized $8^{\text {th }}$ Grade Math/ELA Score & $\begin{array}{c}-0.113 * * * \\
(0.004)\end{array}$ & $\begin{array}{c}-0.107 * * * \\
(0.004)\end{array}$ & $\begin{array}{c}-0.323 * * * \\
(0.065)\end{array}$ \\
\hline Female & $\begin{array}{c}-0.028 * * * \\
(0.007)\end{array}$ & $\begin{array}{c}-0.024 * * * \\
(0.006)\end{array}$ & $\begin{array}{c}-0.075^{*} \\
(0.039)\end{array}$ \\
\hline Black & $\begin{array}{c}-0.021 * * \\
(0.009)\end{array}$ & $\begin{array}{c}-0.022 * * \\
(0.009)\end{array}$ & $\begin{array}{c}-0.099 * * \\
(0.037)\end{array}$ \\
\hline Other Student of Color & $\begin{array}{c}0.005 \\
(0.009)\end{array}$ & $\begin{array}{c}0.006 \\
(0.009)\end{array}$ & $\begin{array}{c}0.056 \\
(0.042)\end{array}$ \\
\hline FRL & $\begin{array}{c}0.037 * * * \\
(0.011)\end{array}$ & $\begin{array}{c}0.037 * * * \\
(0.010)\end{array}$ & $\begin{array}{l}0.058 * \\
(0.034)\end{array}$ \\
\hline SWD & $\begin{array}{c}-0.123 * * * \\
(0.010)\end{array}$ & $\begin{array}{c}-0.109 * * * \\
(0.011)\end{array}$ & $\begin{array}{c}-0.486 * * * \\
(0.069)\end{array}$ \\
\hline School Effects & Yes & Yes & Yes \\
\hline Observations & 18,660 & 18,660 & 18,660 \\
\hline
\end{tabular}


Table A2: Impact of Exclusionary Discipline on Probability of $9^{\text {th }}$ Grade Retention for Students with At Least One Minor Non-Violent Infraction in $8^{\text {th }}$ Grade

(1)

All $8^{\text {th }}-9^{\text {th }}$ Grade Students Student Switchers, $8^{\text {th }}-9^{\text {th }}$ Grade

Any Exclusionary Discipline, $8^{\text {th }}$ Grade

Any Prior Retention, $8^{\text {th }}$ Grade or Below

Standardized Math/ELA Score, $8^{\text {th }}$ Grade

Female

Black

Other Student of Color

FRL

SWD

Disorderly Conduct, $8^{\text {th }}$ Grade

Insubordination, $8^{\text {th }}$ Grade

Other Infraction, $8^{\text {th }}$ Grade

Truancy, $8^{\text {th }}$ Grade

School Effects

Observations
$0.036 * * *$
(0.006)
$-0.003$
$0.075^{* * * *}$
(0.008)
$-0.058 * * *$
(0.003)
$-0.017 * * *$
(0.004)
$-0.015 * * *$
(0.005)
$-0.015^{* *}$
(0.006)
$0.024 * * *$
(0.005)
$-0.057 * * *$
(0.006)
(0.027)
0.023
(0.045)
$-0.141 * * *$
(0.014)
$-0.012$
(0.016)
$-0.016$
(0.019)
0.046
(0.028)
0.041 *
(0.022)
$-0.147 * * *$
0.001
(0.022)
0.009
(0.002)
$0.004 * * *$
(0.008)
(0.001)
0.003
$-0.002$
(0.007)
(0.002)
$0.011 * * *$
0.006
(0.005)
0.022
(0.002)

Yes

Yes

19,294 2,288

$* * * p<0.01, * * p<0.05, * p<0.1$ 